\title{
Workshop on Sustainable Site Productivity in Canadian Forests
}

For over 12 years, the Canadian Forest Service of Natural Resources Canada has sponsored research through the ENFOR (Energy from Forests) Program to verify whether site productivity is sustainable following practices such as whole-tree harvesting. Long-term field experiments were established in several regions of the country under this program, and as these studies began to yield results and information, the ENFOR Committee offered to sponsor a national workshop to share the results of this research with the scientific community and to present an opportunity for discussion of sustainable site productivity in a broader scientific and ecological context.

In February 1997, scientists and forest managers from across Canada and the bordering US states met in Sault Ste. Marie, Ontario for a workshop on "Sustainable Site Productivity in Canadian Forests: Ecosystem Processes Affected by Disturbance and Renewal." The gathering of 130 people provided an opportunity to discuss how natural and humancaused disturbance and renewal processes can affect ecological processes that determine long-term site productivity. An integrated understanding of these processes is necessary if Canada's forests are to be managed in a sustainable manner.

The workshop encompassed studies of soil nutrient and hydrological cycling, vegetation dynamics, soil flora and fauna, site microclimate, soil moisture, and soil physical properties. There was an emphasis on understanding processes following natural disturbance, such as fire, and artificial treatments, such as harvesting and site preparation. Papers included presentations of results from fundamental studies on soil properties and processes, and applied studies aimed at improving management options and predicting responses via modeling.
Sustainable site productivity of Canadian forests is not just a matter for scientific investigation and debate. In order to involve forest managers and policy-makers in the discussion, a joint session with the Ontario Professional Foresters Association was arranged in conjunction with the workshop. A panel featuring academic and industrial speakers discussed trends in policy and management practices associated with sustainable site productivity.

Future needs and opportunities were identified at the close of the workshop. It was concluded that there is a need for more synthesis and integration of the research that has already been done, and to bring current knowledge to bear on critical issues to ensure that there is a sound scientific underpinning for present and future forest management decisions. Currently, most research findings are site-specific and there is a need to extrapolate these regionally and nationally. Modeling has a critical role to play in synthesizing information so that it can be used to predict the impacts of our harvesting practices over at least a full rotation.

Work on sustainable productivity will also be critical in the future in the area of criteria and indicators of sustainable development and forest practices certification. The link has yet to be made between those values defined by society and the sustainability of forests as defined by ecosystems structure and function. The scientific results presented at the workshop furthered attempts to link these two key aspects of sustainable development.

The following three professional papers presented at the workshop offer different perspectives on the issue of long-term site productivity in Canadian forests. Readers interested in the refereed scientific papers presented at the workshop will find them in the current (February 1998) issue of Canadian Journal of Soil Science. 